\title{
CRYOSCOPIC DETERMINATIONS ON TISSUE FLUIDS OF PLANTS OF JAMAICAN COASTAL DESERTS ${ }^{x}$
}

J. ARTHUR HARRIS AND JOHN V. LAWRENCE

\section{Introduction}

PURPOSE OF STUDY.-In a memoir recently published ${ }^{2}$ we have discussed in detail the reasons for considering the physico-chemical properties of vegetable saps a subject of real importance in ecology and phytogeography, and have reinforced the arguments advanced by series of determinations showing distinct differences in the osmotic pressure, or osmotic concentration, as some prefer to call it, of leaf sap from plants growing in different local habitats in the Arizona deserts. A comparison of these determinations with a series made in the more mesophytic region of the Station for Experimental Evolution ${ }^{3}$ demonstrated a conspicuous differentiation of the Tucson and Cold Spring Harbor regions with respect to the osmotic concentration of the tissue fluids of the constituent species. In view of the conspicuous differences established between these two floras, it seemed desirable to select a forested region of as uniformly distributed and as nearly maximum rainfall as possible for comparison with the areas already studied. Thus we hoped to approximate the extreme values of osmotic concentration to be found in xerophytic and hygrophytic regions. For such a study the montane rain forest of the island of Jamaica, recently described by SHREVE, ${ }^{4}$ seemed the most suitable locality. We therefore spent a period of several weeks during the winter and spring months

${ }^{I}$ Studies carried out by the Department of Botanical Research and the Department of Experimental Evolution of the Carnegie Institution of Washington, with"the collaboration of the New York Botanical Garden.

${ }^{2}$ Harris, J. Arthur, and LAWrence, John V., with the co-operation of GorTner, R. A., The cryoscopic constants of expressed vegetable saps as related to local environmental conditions in the Arizona deserts. Phys. Researches 2:1-49. I916.

${ }^{3}$ Harris, J. Arthur, Lawrence, John V., and Gortner, R. A., On the osmotic pressure of the juices of desert plants. Science N.S. $4 \mathrm{r}: 65_{6}-65^{8}$. $19 \mathrm{I}_{5}$.

${ }_{4}^{4}$ SHREve, F., A montane rain forest. A contribution to the physiological plant geography of Jamaica. Publ. Carnegie Inst. Wash. I99. I9r4. 
of I $\mathrm{I}_{5}$ in a study of the osmotic concentration of the tissue fluids of the plants of the montane region. The results of this study will be published later. Fortunately, while in Jamaica we were also able to visit the remarkable coastal deserts of the southern shore. It seemed to us highly desirable to secure as large a series of determinations as possible upon the species constituting their flora for comparison with the observations already made in the Arizona deserts in the neighborhood of the Desert Laboratory. Our purpose in this paper, therefore, is to present a considerable series of novel physiological data on the plants of the desert area of the southern coast of Jamaica; to compare the flora in this regard with that of the southern Arizona deserts and of some other localities; and to hazard some suggestions eoncerning biological factors immediately underlying certain of the differences observed in various species of the coastal region.

Characteristics of Deserts investigated.-Lying as it does in the center of the Carribean Sea, the island of Jamaica intercepts the trade winds in a way to cause a pronounced differentiation in its climatic conditions. This is especially true on the narrow eastern end, where the Blue Mountains, attaining a height of nearly 7500 feet, separate two narrow coast plains. At Port Antonio, at sea level on the northern coast of the island, the mean annual rainfall averages more than 130 inches. At Kingacon, at sea level on the southern coast of the island, precipitation is on the average less than 38 inches per year. Temperature and insolation characteristic of sea level at $18^{\circ} \mathrm{N}$. latitude coupled with local peculiarities of the substratum have here resulted in a conspicuously xerophytic type of vegetation.

As limited by SHREVE 5 , the desert fringes the southern coast of the island from the mouth of the Cane River, just east of Kingston, for a distance of about 70 miles to the Pedro Bluffs. Its greatest area is found in the Healthshire Hills, in the vicinity of Port Henderson, and in Portland Ridge.

As SHREVE points out, the rainfall is capable of supporting a savanna of coarse grasses and large mimosaceous trees wherever the soil is deep, as in the vicinity of Spanish Town, Porus, and May

${ }^{5}$ ShrevE, F., The coastal deserts of Jamaica. Plant World r3:129-134. rgro. 
Pen. The desert is confined to the limestone areas which have an extremely rough surface, with layers or shallow pockets of soil which are not capable of retaining moisture or of deriving it by capillarity, and to the finely ground substratum of the coastal flats. The proximity of the sea and other factors maintain a high relative humidity. Atmometer readings by SHREVE indicate that the evaporation rates here and at Hope Gardens, which is some 6 miles inland and behind a low ridge of hills, are not very different.

All of our collections were made in the immediate vicinity of Port Henderson, a point easily accessible from Spanish Town, where it was possible to carry out the laboratory phases of the work, and which afforded access to both the rocky limestone hills and the coastal flats. Because of military restrictions, made with great courtesy, we were unable to visit all parts of the region. Probably distribution of the collections over a wider area would have modified but little the conclusions here drawn, although it might have increased the number of species upon which determinations are based.

The area considered comprises open beach, a mangrove swamp, a highly saline tract of mud flats practically free of vegetation, somewhat higher-lying flats of finely ground detrital material, and rocky limestone hills, the soil of which is relatively incapable of retaining water.

The determinations which we made on the plants of the open beach and on those of the mangrove swamp are reserved for a discussion of the sap properties of strand and mangrove swamp species, to be published later when data for other habitats (many of which have already been collected) are ready. The vegetation of the exceedingly saline mud flats is practically limited to the two well known halophytes Batis maritima and Sesuvium Portulacastrum, of which the former is much the more common, and the two mangroves Avicennia nitida and Laguncularia racemosa, which occur on the edges of the area. The determinations from this area are also omitted for the present. We restrict ourselves, therefore, to a discussion of the floras of the coastal flats and of the dry hills.

At the time of our visits, in the midwinter and early spring seasons, ephemerals were not seen. Practically' all of our determinations are based upon sclerophyllous arborescent or suffrutescent 
species, or upon cacti. Here, as is generally the case in desert regions, the classification of the plants with respect to growth form presents considerable difficulty. Trees are shrublike in stature and shrubs are correspondingly reduced in size. In spots where the soil is deeper or more retentive of moisture the size of the individuals may be much greater.

Describing the vegetation in terms of the species upon which we were able to secure determinations, we may note that the vegetation of the coastal flats is made up chiefly of a mesquite tree Prosopis juliflora, and a columnar cactus Lemairocereus Hystrix. Other trees or shrubs are Caesalpinia vesicaria, Capparis cynophallophora, C. ferruginea, and Guaiacum officinale. Our lists show determinations for 7 species of cacti. In addition to these, Sesuvium Portulacastrum, Batis maritima, and in places Bromelia Pinguin are abundant. On the rocky hillsides the more truly arborescent forms are Bauhinia divaricata, Caesalpinia vesicaria, Canella Winterana, Capparis ferruginea, Cassia emarginata, Ichthyomethia Piscipula, Melicocca bijuga, Prosopis juliflora, Sarcomphalus Sarcomphalus, Schoepfia chrysophylloides, and Tamarindus indica. The shrubs are Chiococca alba, Croton flavens, Hypelate trifoliata, Lantana crocea (?), Morinda Roioc, Solanum bahamense, and Turnera ulmifolia. The smaller ligneous species are the dwarf shrubs or half shrubs Achyranthes halimifolia, Lantana reticulata, and Jatropha gossypifolia, and the twiners Echites Echites and Phillivertella clausa. The only monocotyledonous plant from which a determination was secured was Bromelia Pinguin. The only herbaceous succulent noted was Bryophyllum pinnatum.

The cacti may also occur on the rocky hills, but in the immediate vicinity of Port Henderson the flora is almost exclusively of small trees and shrubs.

There are but few species in our series of determinations commonto the two habitats. These are Achyranthes halimifolia, Caesalpinia vesicaria, Capparis ferruginea, Jatropha gossypifolia, and Prosopis juliflora.

MEthods.-The very simple technique used in making the determinations has been described in detail elsewhere. ${ }^{6}$ Samples

${ }^{6}$ GoRTNER, R. A., and HARris, J. ARTHUR, Notes on the technique of determining the depression of the freezing point. Plant World $17: 49^{-53}$. 19r4. 
of tissue were collected in test tubes of about roo cc. capacity and taken to the laboratory for freezing by immersion for several hours in an ice and salt mixture, in order to avoid errors in the extraction of sap as noted by Dixon and Atkins ${ }^{7}$ and ourselves. ${ }^{8}$ The sap was then extracted by pressure in a small heavily tinned press bowl with a powerful hand screw. After filtering, the freezing-point lowering of the sap was determined by the use of a thermometer graduated in hundredths of degrees with divisions sufficiently large to permit reading approximately to thousandths of degrees.

In some instances a cloudiness or flocculent precipitate similar to that described by GoRKE 9 was observed when the sap approached the freezing point or passed it in undercooling. We had no facilities for any investigation of these substances, but believe their pressure does not greatly, if at all, influence our results.

The measurements are recorded in degrees depression $(\Delta)$ corrected for undercooling and in atmospheres pressure $(P)$ from a table published elsewhere. ${ }^{\text {ro }}$ The fact that a number of the determinations exceeded the range of the table as originally printed has led to the publication of a supplementary one. ${ }^{\text {Ir }}$

\section{Presentation and analysis of data}

In the following protocol the values to the extreme right opposite the species names are (whenever possible) averages. These averages are designated by bars. The individual readings upon which they are based, with their dates of collection, are entered below the species, except in the cases in which only a single determination is available and must serve, instead of an average, to represent the species.

${ }^{7}$ Dixon, H. H., and Atrins, W. R. G., Osmotic pressures in plants. I. Methods of extracting sap from plant organs. Sci. Proc. Roy. Dublin Soc. N.S. 13:422-433. I913; also in notes from Bot. Sch. Trin. Coll. Dublin 2:154-172. I913.

${ }^{8}$ Gortner, R. A., LAWrence, John V., and Harris, J. Arthur, The extraction of sap from plant tissues by pressure. Biochem. Bull. 5:139-142. pl. 1. I916.

9 GoRkE, H., Über chemische Vorgänge beim Erfrieren der Pflanzen. Landwirthsch. Versuch. Stat. 65:149-160. 1906.

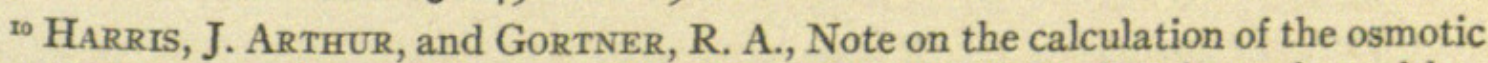
pressure of expressed vegetable saps from the depression of the freezing point, with a table for the values of $P$ for $\Delta=0.001^{\circ}$ to $\Delta=2.999^{\circ}$. Amer. Jour. Bot. $1: 75^{-78}$. I9r 4 ; reprinted in MatTHEW's Physiological Chemistry.

${ }^{I I}$ Harris, J. ARTHUR, An extension to $5.99^{\circ}$ of tables to determine the osmotic pressure of expressed vegetable saps from the depression of the freezing point. Amer. Jour. Bot. 2:418-4I9. 1915. 


\section{A. THE COASTAL FLATS}

The following determinations were made on the sap extracted from the leaves of the small more or less sclerophyllous trees.

Caesalpinia vesicaria L.......................... $\bar{\Delta}=2.95, \bar{P}=35.4$ January $25, \Delta=2.91, P=34.9$

March $26, \Delta=3.08, P=37.0$

March 30, $\Delta=2.87, P=34.4$

Capparis cynophallophora L. (C. jamaicensis Jacq.)...... $\bar{\Delta}=3 \cdot 76, \bar{P}=45.0$ January $30, \Delta=3.87, P=46.4$

April 2, $\Delta=3.64, P=43.6$

Capparis ferruginea L......................... $\bar{\Delta}=4 . \mathrm{I} 2, \bar{P}=49 \cdot 3$

January $25, \Delta=4$. I0, $P=49$. I

March $30, \Delta=4.13, P=49.4$

Guaiacum officinale L......................... $\bar{\Delta}=4 \cdot 35, \bar{P}=52 . \mathrm{I}$

January $25, \Delta=4.48, P=53.6$

March $26, \Delta=4.22, P=50.5$

Prosopis juliflora (L.) DC.................... $\bar{\Delta}=2.53, \bar{P}=30.3$

March 30, $\Delta=2.42, P=29$. I

April 2, $\Delta=2.63, P=31.5$

Three species which may be classified as dwarf shrubs or half shrubs gave

Achyranthes halimifolia Lam.

$\bar{\Delta}=2.86, \bar{P}=34.3$

January 22, $\Delta=3.23, P=38.7$

January $25, \Delta=2.48, P=29.8$

Batis maritima L.......................... $=4.18, \bar{P}=50.0$

January 22, $\Delta=4.18, P=50.0$

January $25, \Delta=3.84, P=46.0$

March 26, $\Delta=4.58, P=54.8$

March 30, $\Delta=4.12, P=49.3$

Jatropha gossypifolia $\mathrm{L} \ldots \ldots \ldots \ldots \ldots \ldots \ldots \ldots \ldots \ldots, \bar{\Delta}=\mathrm{I} . \mathrm{I} 7, \bar{P}=\mathrm{I} 4 . \mathrm{I}$

January $25, \Delta=1.24, P=\mathrm{I} 4.9$

January $30, \Delta=\mathrm{I}$. IO,$P=\mathrm{I} 3.2$

Our visit was not made during the time of the development of ephemeral plants. The only herbaceous form which we secured was the well known halophyte Sesuvium.

Sesuvium Portulacastrum I $\bar{\Delta}=2.86, \bar{P}=34.3$

January $30, \Delta=3.28, P=39.3$

January $30, \Delta=4.03, P=48.3$

March 26, $\Delta=4.17, P=49.9$

March 26, $\Delta=1.94, P=23.3$

March 30, $\Delta=2$. II $P=25.4$

April 2, $\Delta=1.63, P=19.5$ 
A portion of the foregoing species are sclerophyllous and a portion are succulent-leaved plants. The tissues of the Cactaceae, which are the dominant forms on the coastal flats, yield fluids giving the following values:

Cactus Melocactus L.

January 22, for cortex, $\Delta=0.40, P=4.9$ for pith, $\Delta=0.49, P=5.9$

March 30, $\quad \Delta=0.46, P=5.5$

April 2, $\quad \Delta=0.57, P=6.9$

Cephalocereus Swartzii (Griseb.) Britton and Rose

March 30, for cortex, $\Delta=0.59, P=7$. I for pith, $\Delta=0.70, P=8.5$

April 2, for cortex, $\Delta=0.59, P=7 . \mathrm{I}$ for pith, $\Delta=0.69, P=8.3$

Harrisia gracilis (Mill.) Britton

March 26, for cortex, $\Delta=0.53, P=6.3$ Hylocereus triangularis (Mill.) Britton and Rose

January $25, \quad \Delta=0.48, P=5.8$

Lemairocereus Hystrix (Solm Byck) Britton and Rose

for cortex, $\Delta=0.64, P=7.7$

for pith, $\Delta=0.75, P=9.0$

January 25 , for cortex, $\Delta=0.44, P=5.2$ for pith, $\Delta=0.64, P=7.7$

March 26, $\quad \Delta=0.64, P=7.6$

March 30, for cortex, $\Delta=0.53, P=6.3$ for pith, $\Delta=0.57, P=6.9$

April 2, for cortex, $\Delta=0.80, P=9.7$ for pith, $\Delta=0.76, P=9$. .

Opuntia Dillenii (Ker Gawl.) Haw.

January $25, \Delta=0.57, P=6.8$

March 30, $\Delta=0.75, P=9.0$

April 2, $\Delta=0.69, P=8.3$

Opuntia spinosissima Mill.

January $25, \Delta=0.57, P=6.8$

March 26, $\Delta=0.78, P=9.4$

March $30, \Delta=0.72, P=8.6$

April 2, $\Delta=0.93, P=$ II I I

The only monocotyledonous plant studied was the terrestrial Bromelia, which may be included here.

Bromelia Pinguin L................................. $26, \Delta=0.63, P=7.6$ 


\section{B. THE ROCKY HILLS}

The classification of the plants from the rocky hills into trees, shrubs, and other growth forms has been indicated in the foregoing introductory section. Here, therefore, we merely give the results of the determinations in alphabetical order.

Achyranthes halimifolia Lam.

$$
\bar{\Delta}=2.83, \bar{P}=33.9
$$

March 26, $\Delta=3.16, P=37.9$

March 30, $\Delta=2.49, P=29.9$

Bauhinia divaricata L......................... $\bar{\Delta}=3.04, \bar{P}=36.5$

January $27, \Delta=3$. Io, $P=37.2$

January $30, \Delta=2.98, P=35.8$

Bromelia Pinguin L.......................... $\bar{\Delta}=0.58, \bar{P}=7.0$

March 30, $\Delta=0.5^{2}, P=6.3$

April 2, $\Delta=0.64, P=7.7$

Bryophyllum pinnatum (Lam.) Kurz ................. $\bar{\Delta}=0.44, \bar{P}=5.5$

March 26, $\Delta=0.49, P=5.9$

March 30, $\Delta=0.37, P=4.5$

April 2, $\Delta=0.50, P=6.0$

Caesalpinia vesicaria L............... January $27, \Delta=2.26, P=27.2$

Canella Winterana (L.) Gaertn..................... $\bar{\Delta}=3 . \mathrm{I} 8, \bar{P}=38$. I

January $27, \Delta=3.29, P=39.5$

January $30, \Delta=3.06, P=36.7$

Capparis ferruginea L....................... $\bar{\Delta}=3.5^{8}, \bar{P}=42.9$

January $30, \Delta=3.50, P=41.9$

March 26, $\Delta=3.66, P=43.8$

Cassia emarginata $\mathrm{L}$.

$\bar{\Delta}=1.97, \bar{P}=23.6$

January $27, \Delta=1.99, P=23.9$

January $30, \Delta=1.94, P=23.3$

Chiococca alba (L.) Hitch................. January $25, \Delta=3.64, P=43.6$

Croton flavens L................... January $27, \Delta=1.47, P=17.7$

Echites Echites (L.) Britton (Echites umbellata Jacq.)

Hypelate trifoliata Sw. January $27, \Delta=1.78, \underline{P}=21.4$

January $30, \Delta=2.30, P=27.6$

March $30, \Delta=2.38, P=28.6$

Ichthyomethia Piscipula (L.) Hitch............March 30, $\Delta=1.49, P=18.0$

Jatropha gossypifolia L................ January $30, \Delta=1.02, P=12.3$

Lantana crocea Jacq. ?................. March 26, $\Delta=1.60, P=19.2$

Lantana reticulata Pers................. January $27, \Delta=2.14, P=25.7$

Melicocca bijuga L............................ $\bar{\Delta}=\mathrm{I} .87, \bar{P}=22.4$

January $30, \Delta=1.73, P=20.8$

March 30, $\Delta=$ I. $73, P=20.8$

April 2, $\Delta=2.14, P=25.7$ 
Morinda Roioc L.......................... $\bar{\Delta}=1.76, \bar{P}=21.2$

March 26, $\Delta=1.77, P=21.3$

March 26, $\Delta=$ I. $76, P=21$. I

March 30, $\Delta=1.84, P=22$. I

April 2, $\Delta=1.68, P=20.2$

Philibertella clausa (Jacq.) Vail............January $27, \Delta=1.51, P=18.2$ Prosopis juliflora (L.) D.C.............. January $27, \Delta=2.69, P=32.3$ Sarcomphalus Sarcomphalus (L.) (Sarcomphalus laurinus Griseb.)

Schoepfia chrysophylloides (Rich.) Planch... January $27, \Delta=1.63, P=19.6$ January $27, \Delta=2.5^{2}, P=30.2$ January $30, \Delta=2.66, P=32.0$ March 26, $\Delta=2.93, P=35$. I April 2, $\Delta=3.06, P=36.7$

Solanum bahamense L........................... $\bar{\Delta}=1.98, \bar{P}=23.8$

January $27, \Delta=1.85, P=22.2$ January $30, \Delta=\mathrm{I} .6 \mathrm{I}, P=\mathrm{I} 9.4$ March 26, $\Delta=2.25, P=27.0$ March 30, $\Delta=2$. I2 $P=25.4$ April 2, $\Delta=2.09, P=25$. I

Tamarindus indica L..........................

January $30, \Delta=1.76, P=21.2$

March $26, \Delta=1.89, P=22.7$

March 30, $\Delta=1.72, P=20.6$

April 2, $\Delta=1.63, P=19.6$

Turnera ulmifolia L..................January $25, \Delta=3 \cdot 39, P=40.7$

\section{Analysis of data}

In the analysis of these data the first step is to put on one side the two species with more or less succulent leaves, Bromelia Pinguin and Bryophyllum pinnatum, and the cacti. These show low concentrations of about 6-9 atmospheres. They are not at all comparable with the other forms investigated in these deserts and elsewhere and will be discussed separately on a subsequent page.

Of the thin-leaved forms, Jatropha gossypifolia has a thickened, almost succulent stem. It is a form much more characteristic of the coastal flats than of the rocky hillsides. The rather tender leaves yield a sap of lower concentration than that of any other thinleaved species. 
Average CONCENTRATION IN COASTAL DESERTS.-As a preliminary to any further analysis of these data the average values for the two habitats and the different growth forms must be obtained.

For the 5 arborescent species of the coastal flats the general average is given by

$\begin{array}{ll}\text { Caesalpinia } & \bar{\Delta}=2.95, \bar{P}=35.4 \\ \text { Capparis } & \bar{\Delta}=3.76, \bar{P}=45.0 \\ \text { Capparis } & \bar{\Delta}=4.12, \bar{P}=49.3 \\ \text { Guaiacum } & \bar{\Delta}=4.35, \bar{P}=52.1 \\ \text { Prosopis } & \bar{\Delta}=2.53, \bar{P}=30.3 \\ \text { General average } & \frac{42.42}{3.542 \quad 42.4}\end{array}$

The 3 species of the coastal flats which have been classified as dwarf shrubs differ greatly in concentration. Achyranthes is a rather hard-leaved halophyte which does not penetrate to the most saline spots. It is characterized by a concentration of about 34 atmospheres as compared with about 50 atmospheres in the highly succulent Batis maritima, the sole species found in the more saline spots. Sesuvium Portulacastrum is characteristic of only the less saline portions of the flats, and shows a far lower average concentration, although some of the individual values attain about the average for Batis.

The actual averages are: mean depression, $2.737^{\circ}$; mean concentration, 32.80 atmospheres.

For the more truly arborescent species of the rocky slopes the values are:

\begin{tabular}{lr} 
Bauhinia & $\bar{\Delta}=3.04, \bar{P}=36.5$ \\
Caesalpinia & $\Delta=2.26, P=27.2$ \\
Canella & $\bar{\Delta}=3.18, \bar{P}=38.1$ \\
Capparis & $\bar{\Delta}=3.58, \bar{P}=42.9$ \\
Cassia & $\bar{\Delta}=1.97, \bar{P}=23.6$ \\
Ichthyomethia & $\bar{\Delta}=1.49, P=18.0$ \\
Melicocca & $\bar{\Delta}=1.87, \bar{P}=22.4$ \\
Prosopis & $\Delta=2.69, P=32.3$ \\
Sarcomphalus & $\bar{\Delta}=1.63, P=19.6$ \\
Schoepfia & $\bar{\Delta}=2.79, \bar{P}=33.5$ \\
Tamarindus & $\bar{\Delta}=1.75, \bar{P}=21.0$ \\
General average & \multicolumn{2}{|c|}{2.388} & 28.6
\end{tabular}


The general average for the shrubs, half shrubs, and woody twiners of the rocky slopes is given by

$\begin{array}{ll}\text { Achyranthes } & \bar{\Delta}=2.83, \bar{P}=33.9 \\ \text { Chiococca } & \Delta=3.64, P=43.6 \\ \text { Croton } & \Delta=1.47, P=17.7 \\ \text { Echites } & \Delta=1.78, P=21.4 \\ \text { Hypelate } & \bar{\Delta}=2.34, \bar{P}=28.1 \\ \text { Jatropha } & \Delta=1.02, P=12.3 \\ \text { Lantana } & \Delta=1.60, P=19.2 \\ \text { Lantana } & \Delta=2.14, P=25.7 \\ \text { Morinda } & \bar{\Delta}=1.76, \bar{P}=21.2 \\ \text { Philibertella } & \Delta=1.51, P=18.2 \\ \text { Solamum } & \bar{\Delta}=1.98, \bar{P}=23.8 \\ \text { Turnera } & \Delta=3.39, P=40.7 \\ \text { General average } & \frac{2.122}{25.48}\end{array}$

Thus the concentrations determined for the smaller forms are practically as large as those for the more truly arborescent species.

Combining all the ligneous perennials of the rocky slopes (that is, omitting from the whole series of determinations only Bromelia and Bryophyllum), we have for the general average of the species means or species constants: mean depression, $2.249^{\circ}$; mean concentration, 27.000 atmospheres.

Combining both arborescent and suffrutescent growth forms, excepting only the herbaceous Sesuvium Portulacastrum, Bromelia, Bryophyllum, and the cacti, the values for the 31 species means or constants of the two habitats recognized give the following averages: mean depression, $2.505^{\circ}$; mean concentration, 30.05 atmospheres. By including the herbaceous perennial Sesuvium, the averages for $3^{2}$ species means or determinations is changed to $\bar{\Delta}=2.5$ I $6, \bar{P}=30.18$.

COMPARISON OF CONSTANTS WITH THOSE FOR MESOPHYTIC REGIONS. - The first question to be answered in the analysis of these data is that concerning the relative values of osmotic concentration in the sap of desert and mesophytic plant organisms. Specifically, do the results of this study confirm those obtained by Firming ${ }^{12}$ in

${ }^{12}$ Frrrrng, H., Die Wasserversorgung und die osmotischen Druckverhältnisse der Wüstenpflanzen. Zeitschr. Bot. 3:209-275. 1911. 
his plasmolytic studies of the plants of North African deserts and by ourselves in our cryoscopic determinations in the Arizona desert region? With an affirmative answer to this question, a second one concerning the closeness of agreement between the two desert areas so far investigated is open to discussion.

Comparisons of the constants for sap properties here secured with those for other regions must be drawn with care and in only a preliminary fashion. This is quite obvious because of the many factors which may influence the constants, but concerning which little or no quantitative data are at present available. For example, the determinations for the Arizona deserts are based on collections made during the period of spring vegetative activity following the winter and spring rains; those for the coastal deserts were made during the dry winter season. The collections made on Long Island and in St. Louis at the Missouri Botanical Garden comprise deciduous species whose leaves must have developed during the spring of the same year. The age of the leaves of the desert plants is often quite indeterminable. Bearing these limitations in mind and remembering that there are probably many others, we note first of all that in a general way the flora of the Port Henderson deserts is in excellent agreement with that of the Tucson region in showing a high concentration of the tissue fluids of its constituent species. The exceptions only emphasize the rule.

Thus comparing the Port Henderson averages for ligneous perennials with those tentatively drawn from unpublished data for trees and shrubs for the Cold Spring Harbor region, ${ }^{{ }^{13}}$ we find

Cold Spring Harbor, 14.40 atmospheres

Jamaican coastal desert

Coastal flats only, $38.8 \mathrm{I}$ atmospheres

Rocky slopes only, 27.00 atmospheres

Flats and rocky slopes, 30.05 atmospheres.

${ }_{13}$ The averages given for both the Cold Spring Harbor and the Tucson series are means of determinations, not of species means. The difference is here quite immaterial. The Cold Spring Harbor means are based on determinations made in 1914 by Gortner, LAwrence, and Harris. They will be replaced shortly by those representing not merely determinations made in I9 $_{4} 4$ but far more extensive work by LAWRENCE and HARRIS in I915 and subsequent work by HARRIS. The field work has been done for a summer series from the Arizona deserts, but the data cannot be completely worked up for some months. 
It is idle to go further into these comparisons. It is clear that the ligneous plants of the Jamaican coastal desert, those of the rocky hills as well as of the more or less saline flats, are characterized by concentration of tissue fluids about twice as great as those of the Cold Spring Harbor region.

The extensive series of species studied by OHLWEILER ${ }^{\text {I4 }}$ suffer from the disadvantage (in relation to the present paper) of being assembled from their natural habitats and grown in a Botanical Garden. All, however, are forms capable of growth in the open at St. Louis. These show a range of from about 7 to about 24 atmospheres. The average value of the 90 determinations is 14.96 atmospheres. Thus, OHLwEILER's St. Louis series agrees very closely with our own preliminary average for Long Island habitats. Here again the values are only about half as high as those determined in the coastal deserts.

COMPARISON OF CONSTANTS WITH THOSE FOR TUCSON REGION.Turning to averages for a comparison of the concentration of the sap of the Jamaican coastal and the Arizona desert floras, the results for ligneous perennials only are: Arizona series, 24.97 atmospheres; Jamaican series, 30.05 atmospheres. Apparently concentration is somewhat greater in the Jamaican series. If the comparison between the two desert areas is to be drawn on a more analytical basis, it may be noted that the values determined for the trees of the coastal flats are of the same order of magnitude as those derived from the species of Atriplex examined in the Arizona salt spots. For example:

$\begin{array}{ll}\text { Atriplex canescens } & P=39.5 \\ \text { Atriplex canescens } & P=67.5 \\ \text { Atriplex canescens angustifolia } & P=32.8 \\ \text { Atriplex polycarpa } & P=52.0\end{array}$

In the Jamaican coastal deserts the trees and shrubs from the rocky slopes show concentrations lower than those of the coastal flats. In the Arizona deserts the plants of the rocky slopes show far lower osmotic concentrations than do those of the salt spots. Comparing Arizona and Jamaican rocky slopes the results are:

${ }^{14}$ OHLWEILER, W. W., The relation between the density of cell saps and the freezing point of leaves. Ann. Rept. Mo. Bot. Gard. 23:101-131. pl. 6. rgr2. 
Port Henderson region, 27.00 atmospheres; Tucson region, 22.0I atmospheres.

With the exception of the salt spots, the bajada slopes of the Tucson region show the highest concentration. Comparing with the rocky slopes of the coastal region, the results are: Port Henderson rocky slopes, 27.00 atmospheres; Tucson region, bajada, 30.34 atmospheres.

Because of seasonal differences it is undesirable to attempt to analyze too closely the differences between the two desert areas. Such could be done if determinations upon the coastal deserts immediately subsequent to a rainy season were available. Until such data are at hand and until our determinations for the summer flora of the Arizona deserts are ready for publication, it is premature to discuss the matter further than to say that both of these regions show concentrations far higher than do those of mesophytic habitats, and that they are in good general agreement between themselves.

OsMotic CONCENTRATION IN THE CACTI.-From the floristic standpoint the most striking feature of these coastal deserts is the remarkable growth of arborescent cacti in immediate proximity to dense mangrove swamps. From the physiological standpoint the most remarkable result of these studies is the demonstration that the fluids of these cacti have about the same concentration as those of other desert regions.

The 28 determinations made on the sap of the 7 species belonging to the 6 genera of cacti show a range of $\Delta=0.40$ to $\Delta=0.93$, or $P=4.9$ to $P=\mathrm{II}$.I, with an average for the series of $\bar{\Delta}=0.626$ and $\bar{P}=7.52$. Yet these cacti are growing in the same substratum as sclerophyllous arborescent species with an average concentration for the species of $\bar{\Delta}=3.54$ and $\bar{P}=42.4$. Much of the cactus-covered area has a dense undergrowth of Batis maritima, which has an average of $\bar{\Delta}=4 \cdot 18, \bar{P}=50.0$. Sesuvium, which sometimes occurs but is not so abundant as Batis among the cacti, has sap averaging $\bar{\Delta}=2.60, \bar{P}=31.2$. Better illustrations of the diverse reaction of two organisms to the same general environmental situation could hardly be found. These results are in close agreement with the findings of those who have worked on the cacti in other regions. 
As early as 1905 CAvARA $^{15}$ investigated a series of cacti by the freezing-point lowering method and gave values not very dissimilar from our own. Sap was extracted from untreated tissue. This may result in abnormally low values of the measures of osmotic concentration.

MACDOUgal and CANNON ${ }^{16}$ have estimated the following concentrations in atmospheres for sap of cacti at $25^{\circ} \mathrm{C}$ : Carnegiea gigantea, 6.78; Echinocactus Wislizenii, 5.72; Opuntia Blakeana, 8.88 and $O$. versicolor, II .98.

It is interesting from the historical standpoint to note that cacti, which with certain other succulents are quite anomalous among desert plants, were perhaps the first to be considered in relation to the problem of the dependence of absorption of water by desert plants upon higher osmotic pressure of their sap. Thus LIVING$\mathrm{STON}^{17}$ concluded, from determinations by the freezing-point, boiling-point, and tissue curvature methods, that the saps of Cereus, Echinocactus, and Opuntia "exhibit osmotic pressures no higher than those commonly found in plants of the humid regions. For these cacti at least, therefore, adaptation to desert conditions is not manifest in increased concentration of the cell sap."

From the foregoing account we may say that the cacti of the Jamaica coast exhibit sap concentration of roughly the same order of magnitude as do those of other regions. Possibly they are somewhat higher than those of purely non-saline localities, but until series in which standard methods of sap extraction have been employed are available from other habitats this cannot be asserted to be the case. Certainly the cacti, with Bromelia and Bryophyllum, are conspicuous exceptions to the general rule of high osmotic concentration in these coastal forms. To this point we shall recur later.

\section{Results}

In the foregoing paragraphs we have shown that the sap of the plant species of the Jamaican coastal deserts has an osmotic

${ }^{25}$ Cavara, F., Risultati di una serie di ricerche crioscopiche sui vegetati. Cont. Biol. Veg. R. Ist. Bot. Palermo 4:4I-80. 1905 .

${ }^{16}$ MAcDougal, D. T., and Cannon, W. A., The conditions of parasitism in plants. Publ. Carnegie Inst. Wash. r29. Igro.

${ }^{n}$ Lrvingston, B. E., The relation of desert plants to soil moisture and evaporation. Publ. Carnegie Inst. Wash. 50. 1906. 
concentration far higher than those of mesophytic regions, and quite equal to if not slightly higher than those of the winter vegetation of the Arizona deserts.

While determinations based on these species growing in other environments are as yet too few to justify detailed discussion, it seems most probable that the properties of their sap are due in part to the local conditions and not merely to the existence here of a series of species characterized by high concentration..$^{18}$

In the few cases in which constants for a species were obtained from the coastal flats and from the rocky slopes, the values from the slopes are generally lower than those from the flats. Thus the single determination on Caesalpinia vesicaria from the slopes gives 27.2 atmospheres as compared with $34.4,34.9$, and 37.0 from the flats. Capparis ferruginea from the slopes gives $4 \mathrm{r} .9$ and 43.8 atmospheres as compared with $49 . \mathrm{I}$ and 49.4 atmospheres when growing on the flats. Jatropha gossypifolia gives $\mathrm{I} 2.3$ atmospheres on the slopes as compared with $\mathrm{I}_{3} .2$ and $\mathrm{I} 4.9$ on the flats.

In the case of Prosopis juliflora and Achyranthes halimifolia, the result is uncertain. The two collections of Achyranthes from the slope gave 29.9 and 37.9 as compared with 29.8 and 38.7 atmospheres for the flats. Prosopis on the slopes yielded sap with a concentration of $3^{2} .3$ atmospheres as compared with two readings of 29 . I and $3 \mathrm{I} .5$ from the flats.

To what extent the osmotic concentration of the sap of the sclerophyllous forms is influenced by the actual presence of salt in the leaves can only be determined by special methods. The leaves of some of the forms growing on the coastal flats, for example Capparis ferruginea, are perceptibly salty to the taste; others are not. It can hardly be doubted that the enormous variation in the concentration of the leaf fluids of such forms as Batis maritima and Sesuvium Portulacastrum, the leaves of which are practically reinforced water bags, is due primarily to electrolytes absorbed from the soil. The fact that the various cacti are here characterized by sap of low concentration, as when growing in true desert environ-

${ }^{18}$ A collection of the leaves of Guaiacum officinale from Spanish Town gave only $\Delta=2.66, P=31.9$ as compared with two constants each over $4^{\circ}$ (50 atmospheres) in the coastal flats. 
ments, indicates that the absorption of any considerable quantity of salts and their retention in solution is not a.necessary result of existence in a saline substratum. Some physiologists have suggested that the high osmotic concentration of the fluids of desert plants is due primarily and directly to greater quantities of soluble material in the substratum than generally occurs in regions of higher rainfall. The validity of the conclusion is rendered highly improbable by the high concentrations demonstrated for the plants of the rocky hillsides.

While in general it is better to reserve hypotheses concerning the peculiarities of individual species until theoretical discussions of their relation to environmental factors can be replaced by inductions from actual quantitative data secured in the particular habitat under investigation, it may be useful to other workers, especially in the case of a problem requiring so many different kinds of specialized observation in a habitat not easily accessible to most botanists, to point out certain possible interpretations of the observed phenomena.

The question of greatest interest is that concerning the difference in behavior of the several species of the same habitat, say the coastal flats. For example, the leaves of Prosopis and Caesalpinia yield sap of a distinctly lower concentration than do those of Guaiacum and the two species of Capparis. Jatropha gossypifolia has sap of only about one-fourth of the concentration of that of Batis maritima, with which it is so generally associated. The cacti and the terrestrial bromeliad exhibit only a fraction of the freezingpoint lowering shown by the hard and succulent leaves of the arborescent and suffrutescent species among which they are interspersed.

Any suggestion in interpretation of these phenomena must be purely tentative and be substantiated by, or discarded on the basis of, actual field studies. Those which are here called to the attention of ecologists are not at all speculative, but merely the result of an attempt to correlate the results of studies by a number of specialists in the various fields of desert botany.

Sesuvium Portulacastrum and Batis maritima are both species with highly succulent leaves. In both, the high osmotic concentration 
of the leaf sap must be due primarily to electrolytes absorbed directly from the substratum. The difference between them, in so far as facts are available, seems to be an inherent physiological one. Sesuvium seems to be a form less tolerant of a highly concentrated soil solution than Batis. The local distribution of the two, therefore, is not at all comparable, and the distinctly higher concentration in the leaves of Batis is probably attributable to this fact.

The only suggestion which can be made concerning the anomalous position of Prosopis among the small trees is that it has a more deeply penetrating root system which taps underflow water, poor in solutes, derived by seepage from the neighboring limestone hills. ${ }^{19}$ From the extensive observations in the deserts of southern Arizona it is known that the related species Prosopis velutina is characterized by deep root penetration. Thus SPALDING $^{20}$ and CANNON ${ }^{21}$ both note the wide horizontal and the deep vertical distribution of the root system, which may reach a depth of $8 \mathrm{~m}$. or over. CANNON ${ }^{22}$ concludes that with uniform and penetrable substratum the species becomes a tree where the perennial ground water does not lie at a depth greater than $50 \mathrm{ft}$.

Such differences as exist between the concentration in the leaves of Prosopis and those of Batis maritima may be accounted for on the grounds of a much higher concentration of salts in the superficial soil layers.

It is interesting to note in this connection that Prosopis juliflora from the coastal deserts gives values of osmotic concentration in general agreement with $P$. velutina of the Arizona deserts. Thus two determinations made on young leaves in the spring of $1914^{23}$ gave:

$$
\begin{array}{ll}
\text { Santa Catalina Mountains, } & \Delta=2.08, P=25.0 \\
\text { Tucson Mountains, } & \Delta=2.33, P=27.9
\end{array}
$$

${ }^{29}$ This suggestion was originally made by SHREvE (loc. cit.) to account for the presence of Prosopis in association with Batis maritima and other halophytes.

${ }^{20}$ Spalding, V. M., Distribution and movements of desert plants. Publ. Carnegie Inst. Wash. I13. 1909.

${ }^{2}$ Cannon, W. A., The root habits of desert plants. Publ. Carnegie Inst. Wash. I3I. I9II.

${ }^{2}$ CANnon, W. A., Some relations between root characters, ground water, and species distribution. Science, N.S. 37:420-423. 19r3.

${ }^{23}$ Physiol. Researches 2:32. I916. 
Hitherto unpublished determinations made in the summer of IgI 6 by LEAMON and HARRIS give:

Santa Catalina bajada

Edge of arroyo, July 6, Same tree, August r4, Upper bajada, July 6, Near San Xavier Mission

Mesa-like slopes, July $24, \quad \Delta=2.5 \mathrm{I}, P=30$. I

$$
\begin{aligned}
& \Delta=2.63, P=31.6 \\
& \Delta=2.40, P=28.8 \\
& \Delta=2.87, P=34.5
\end{aligned}
$$

Surely no one will venture to assert on the basis of the available data that the Jamaican Prosopis juliflora and the southwestern $P$. velutina are sensibly different in osmotic concentration.

With regard to the cacti, which have been shown elsewhere in this paper to have about the same concentration of tissue fluids as those found for this group growing in other habitats, the following points must be taken into account. The cacti are plants characterized by a deeply penetrating anchoring root system and a farreaching superficially placed absorbing system. The evidences upon which this statement is based are chiefly those presented by CANNON in his large paper on the root habits of desert plants. If the coastal species agree in this regard with the forms which have been investigated, their absorbing organs are in contact with the actually dryest zone of the substratum during periods of severe drought, and with one physiologically dry, that is, characterized by a soil solution of high osmotic concentration, during periods of moderately abundant soil moisture.

Such are the conditions which result in the high concentration found in Batis maritima, and one might, at first thought, suppose that the cacti would also be subject to the same conditions. Two additional factors, however, are to be taken into account: (I) the cacti are organisms capable of rapid storage of water during transient periods of soil saturation, ${ }^{24}$ and its persistent retention during

${ }^{24}$ The point is splendidly illustrated by two photographs of Opuntia published by Cannon (Amer. Nat. 40:27-47. figs. 2-3. 1906). MacDougal and Spalding (The water balance of succulent plants. Publ. Carnegie Inst. Wash. 14r. 1910) have dealt with the problem in greater detail. A number of other papers bearing more or less directly upon the general problem of water absorption and storage in the cacti have since appeared from the Desert Laboratory. 
long periods of deprivation; (2) the rainfall in the Jamaican coastal desert region is not distributed uniformly throughout the year. During periods of heavy rainfall the salts would be highly diluted or even largely washed out of the superficial soil layers in which the absorbing roots of the cacti lie, thus permitting water intake in quantities quite sufficient to maintain the plant until conditions again become favorable for water absorption. Thus species may differ very greatly in the relationship of their sap properties to environmental factors. Two species may be rooted in the same substratum, but because of differences in root penetration or in their capacity for water absorption or retention in reality they may be living in very different environments, or reacting quite differently to the same environment.

Whether the hypotheses just advanced in explanation of the great diversity of the constants determined on the sap of particular species of plants growing in the same habitat be correct, can only be determined by intensive observational and experimental studies in the field. In the meantime they seem consistent with the available facts of desert plant physiology.

\section{Recapitulation}

In the present paper, which is one of a series on the physicochemical properties of the tissue fluids of the plants of typical vegetations, we have presented the results of determinations of the freezing-point lowering of the tissue fluids of the plant species of the Jamaican coastal deserts; have compared the constants secured with those already available for the Arizona deserts and for mesophytic habitats; and have offered tentative suggestions concerning the proximate causes of certain of the observed peculiarities of individual species.

The deserts investigated constitute a small area on the southern coast of the island, where not merely the reduction in the rainfall due to the interception of the trade winds by relatively high mountains, but peculiarities of the substratum, contribute to the rigor of conditions limiting plant growth.

Two sub-habitats have been recognized, low-lying coastal flats of finely ground detrital material, to a considerable extent impreg- 
nated with salts, and rocky limestone hills incapable of retaining moisture or of deriving it by capillarity.

The vegetation of the coastal flats comprises a number of hardleaved trees, among which is a mesquite very similar to that of the deserts of the southwestern United States, some thin and some succulent-leaved halophytes, and a number of genera and species of cacti which form a luxuriant stand. The vegetation of the rocky hills is of a more arborescent type, consisting chiefly of dwarfed broad-leaved trees with a number of small dwarf or half shrubs which have few purely structural characteristics which would ally them to desert plants.

Taken as a whole, the species of the Jamaican coastal deserts show a concentration of their tissue fluids quite as high as, if not slightly higher than, that of as nearly as possible comparable growth forms in the Arizona deserts. The concentration of the leaf sap of the ligneous forms averages about two or three times that demonstrated in mesophytic regions.

While the plants of the rocky slopes show high concentrations, higher indeed than do those of the rocky slopes of the Arizona deserts, their constants are distinctly lower than those of the species of the coastal flats.

The sap of the cacti has only a fraction of the osmotic concentration of that of the hard or succulent leaves of the trees and half shrubs among which they are rooted. The succulent Bryophyllum pinnatum and the terrestrial bromeliad Bromelia Pinguin show far lower concentrations than do the other species. Furthermore, Prosopis juliflora exhibits sap concentrations distinctly lower than those of certain other of the arborescent species. These form the extreme illustration of the fact that species of the same habitat show marked differences in sap properties. Suggestions concerning the underlying causes of such differences are offered.

Station For ExpErimental Evolution

Cold SPRING Harbor, LoNg IsLANd, N.Y. 


\section{$2 \mathrm{BHL}$ Biodiversity Heritage Library}

Harris, J Arthur and Lawrence, John V . 1917. "Cryoscopic Determinations on Tissue Fluids of Plants of Jamaican Coastal Deserts." Botanical gazette 64(4), 285-305. https://doi.org/10.1086/332132.

View This Item Online: https://www.biodiversitylibrary.org/item/109348

DOI: https://doi.org/10.1086/332132

Permalink: https://www.biodiversitylibrary.org/partpdf/223929

\section{Holding Institution}

Missouri Botanical Garden, Peter H. Raven Library

\section{Sponsored by}

Missouri Botanical Garden

\section{Copyright \& Reuse}

Copyright Status: Public domain. The BHL considers that this work is no longer under copyright protection.

This document was created from content at the Biodiversity Heritage Library, the world's largest open access digital library for biodiversity literature and archives. Visit BHL at https://www.biodiversitylibrary.org. 